\title{
Knowledge based Expert System for Predicting Diabetic Retinopathy using Machine Learning Algorithms
}

\author{
J.Jayashree, Sruthi R, Ponnamanda Venkata Sairam, J.Vijayashree
}

\begin{abstract}
Diabetic retinopathy (DR) is a medical condition that can affect the patient's retina and cause leaks in the blood due to diabetes mellitus. The increase in cases of diabetes limits existing manual testing capability. Today new algorithms are becoming very important for assisted diagnosis. Effective diabetes diagnosis can benefit the victims and reduce the negative harmful effects, including blindness. If not treated in a timely manner, this disorder can cause different symptoms from mild vision problems to total blindness. Early signs of $D R$ are the hemorrhages, hard exudates, and micro-aneurysms (HEM) that occur in the retina. Timely diagnosis of HEM is important for avoiding blindness This paper presents PSO feature selection algorithms with three classifications for the detection of Diabetic retinopathy using python.
\end{abstract} classification, Complications, Treatment, Prevention, Statistics.

\section{INTRODUCTION}

Diabetic retinopathy is the undergoing changes that take place in blood sugar levels throughout the capillary of the retinal system. Some vessels may swell up in some cases, and fluid leaks into the back of the eye. These could swell and drop in the capillary. Or they could close, blocking the flow of blood. Anomalous new capillary often grow up on the retina. All these improvements will rob your eyesight. DR was not leading symptoms initially, just low vision complications. Ultimately, that it will lead blindness. Whoever also type 1 and type 2 diabetic can develop the condition. The you have far more diabetes, and the less sugar on your blood regulated, the greater the probability that you will experience this eye complication. In other cases abnormal arteries will grow on the ground of the retina. Over time, too much blood sugar will contribute to blocking the tiny capillary that feed the retina and sever blood supply. As a consequence, the eye looks for new capillary development

\section{A. Types of diabetic retinopathy}

There are two types of diabetic retinopathy:

Early diabetic retinopathy Commonly known as -non proliferative diabetic retinopathy (NPDR) which occurs when there isn't growth/proliferating of new capillary.

Revised Manuscript Received on April 25, 2020.

J. Jayashree*, School of Computer Science and Engineering, VIT,Vellore vijayashree.j@vit.ac.in

Sruthi R, School of Computer Science and Engineering, VIT,Vellore Ponnamanda Venkata Sairam, School of Computer Science and Engineering, VIT,Vellore

J. Vijayashree, School of Computer Science and Engineering, VIT,Vellore

(C) The Authors. Published by Blue Eyes Intelligence Engineering and Sciences Publication (BEIESP). This is an open access article under the CC BY-NC-ND license (http://creativecommons.org/licenses/by-nc-nd/4.0/)
Keywords: Diabetic retinopathy, feature selection,

That is the initial phase of Diabetes eye disease. The walls of the capillary within the retina weaken when you have NPDR. Smaller bulges (microaneurysms) extend down from the walls of the smaller vessels, frequently withering fluid and blood into another retina. Greater retinal shafts, too, may start dilating and radius is abnormal. NPDR can switch from mild to severe, as more siege capillary. Capillary within the eye can also close off with NPDR. This is called ischemia macular. When this occurs, the macula cannot be penetrated by blood. Occasionally, small particles, termed exudates, could perhaps form in the retina. Nerve fibers in the retina can start swelling. Central segment of the retina (macula) sometimes starts swelling (macular edema), an ailment which needs medical attention. Advanced diabetic retinopathy, known as proliferative diabetic retinopathy, can progress to this more serious type. In this case, damaged capillary narrow off, brings new prosperity, irregular capillary of retina, and may dip into the transparent, fliud-like fluid that filling your (vitreous) middle of eye. PDR is the most advanced stage of eye disease for diabetics. It happens when new capillary start to grow in the retina. Neovascularization is called this. Often those delicate bleeding current vessels into the pigment particles. You might see some gloomy gnats, when they bleed a little. When it spills a lot, then all vision could be blocked. Finally scar tissue, eventually aroused by the development of new capillary, can induce the retina to divide from either the rear in your eye. Unless the new capillary interacts with ordinary fluid flow out from the eye, stress in the eye ball will accumulate. This can disrupt the nerves that brings stimuli (optic nerve) of your eye to your brain, contributing to macular degeneration. The body's effort to save its retina is proliferative retinopathy, but it can often lead to retina scarring and can cause the retina to detach itself, leading to blindness. Modern eye care can help prevent blindness from arising as a result of proliferative retinopathy.

\section{B. Stages of diabetic retinopathy}

\begin{tabular}{|l|l|l|l|}
\hline & STAGES & $\begin{array}{l}\text { DESCRIPTI } \\
\text { ON }\end{array}$ & IMAGE \\
\hline 1 & $\begin{array}{l}\text { Mild } \\
\text { Nonproliferative } \\
\text { Retinopathy }\end{array}$ & $\begin{array}{l}\text { Microaneurysms } \\
\text { occur at this } \\
\text { stage. These are } \\
\text { small pockets of } \\
\text { globular swelling } \\
\text { in the relatively } \\
\text { small capillary of } \\
\text { the eye. }\end{array}$ & \\
\hline
\end{tabular}

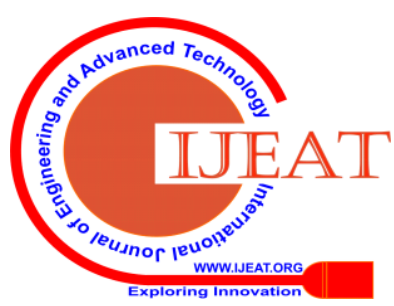




\begin{tabular}{|l|l|l|}
\hline 2 & $\begin{array}{l}\text { Moderate } \\
\text { Nonproliferative } \\
\text { Retinopathy }\end{array}$ & $\begin{array}{l}\text { This is the phase } \\
\text { where blocking } \\
\text { of capillary } \\
\text { occur. }\end{array}$ \\
\hline 3 & $\begin{array}{l}\text { Severe } \\
\text { Nonproliferative } \\
\text { Retinopathy }\end{array}$ & $\begin{array}{l}\text { The capillary } \\
\text { which helps for } \\
\text { the nourishment } \\
\text { of eye are } \\
\text { blocked thus } \\
\text { signalling the } \\
\text { retina to grow } \\
\text { new capillary. }\end{array}$ \\
\hline 4 & $\begin{array}{l}\text { Proliferative capillary } \\
\text { Retinopathy }\end{array}$ & $\begin{array}{l}\text { were } \\
\text { proliferating, } \\
\text { expanding within } \\
\text { the retina, and } \\
\text { into the vitreous } \\
\text { gel. }\end{array}$ \\
\hline
\end{tabular}

\section{Symptoms}

The initial stages of diabetic retinopathy will occur without signs or discomfort like many conditions of this nature. There will not be any direct effect on the vision when sickness progresses. Macular oedema might led to maculopathy and affects vision if leakage induces swelling of the macular fluid. Signs become obvious when the disease progresses, the normal retinopathy side effects to be observed also include:

- Blurry vision

- Spots and floaters in eye

- Double vision

- Eye pain

\section{Risk Factors}

Someone living with diabetes may develop diabetic retinopathy. This may increase the probability of cultivating the eye condition:

- High blood sugar level

- High blood pressure

- Higher levels of protein content in urine

- Raised obesity in the blood

- High levels of cholesterol

- Use of Tobacco

Whoever has diabetes may grow diabetic retinopathy and other diabetes problems. The more a patient seems to get diabetes, the higher the risk of developing diabetic retinopathy. In addition, patients should always be informed that a rapid increase in blood glucose levels will result to retinopathy which is worse. In this scenario, a massive increase in blood sugar levels characterized by either a $30 \mathrm{mmol} / \mathrm{mol}$ or 3 percent reduction in HbA1c.

\section{E. Complications of DR}

Diabetic retinopathy includes the development of irregular blood vessels within that retina. Abnormalities can cause major problems regarding vision::

- Vitreous haemorrhage. The fresh capillary can bleed into the fresh, creamy-like stuff, covering the middle of your eye. Where the rate of leakage is low, you can only see some dark spots (floaters).

Blood will fills the vitreous cavity in more severe cases and effectively block your vision. If the vitreous humor shrinks, these capillary can be weakened, causing them to bleed, which can contribute to the appearance of cobwebs in your eyes and make it harder to see. Blood from a vitreous haemorrhage can dissipate, but any complications would require medical attention.

Vitreous haemorrhage on its own does not usually cause irreversible loss of vision. Often the blood clears within a few weeks or months from the eye. Without harm to your retina, the vision can revert to its former clarity.

- Retinal tightening. The enlarged capillary correlated with macular degeneration facilitates the development of scar tissue which may remove the retina from the back of the eye.

- Glaucoma. New capillary must develop at the front of of your eye and collide to your eye's ordinary fluid flow, allowing pressure to build up in your eye (glaucoma). The above pressure may disrupt the nerve which carries images of your eye in your nervous system (antenna nerve).

- Blindness. Diabetic retinal detachments, cataracts or both ultimately result in total vision lost.

Treatment may include one or more of:

- Laser therapy - To help new capillary rising

- Anti-VEGF treatments - prevents the growth of new capillary but is a more expensive treatment.

\section{F. Prevention}

Diabetic retinopathy is not always preventable. Regular eye tests, handling stable blood glucose and heart rate, and early intervention of vision problems may help prevent serious loss of vision, however. Decrease the level your risk of diabetic retinopathy when you suffer from diabetes by doing the following:

- Monitor your diabetes: Consider the daily routine part of healthy eating and physical activity. Seek minimum 150 minutes of medium aerobic exercise every week, for example walking. Take drugs or insulin for oral diabetes as prescribed.

- Track the blood glucose level: You might need blood sugar monitoring and log them out many times a day - you may need more regular tests when you happen to be sick or under tension. Request your physician how frequently you need to check sugar in blood.

- Keep levels of cholesterol control balance: Healthy eating, doing daily workouts and dropping muscle mass will help. Medication is also often required.

- Quit Smoking: Smoking will increase the risk of several diabetes problems.

- Beware of shifts in vision. Whether you notice sudden changes in vision, or your vision is blurred, spotty or hazy, call your eye doctor right away.

Blue Eyes Intelligence Engineering

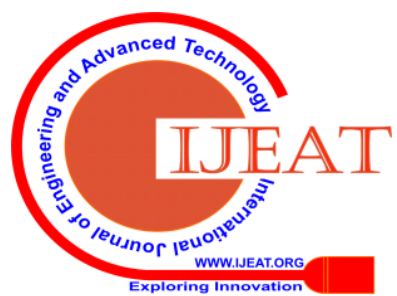




\section{G. Statistics}

Background retinopathy

Among diabetes sufferers some type of retinopathy is normal. A 2002 Royal Liverpool University Hospital study examined 820 type 1 diabetes patients and 7,271 type 2 diabetes patients and made the following results:

- Some form of retinopathy was found in 46 percent of individuals with type one diabetes

- Some levels of the retinopathy was observed in 25.3 percent of individuals with type 2 diabetes

The greater occurrence of retinopathy in seen among individuals having type 1 than those with type 2 diabetes.

Table -II: Zone wise distribution of monitored diabetic patients, and area wise occurrence.

\begin{tabular}{|l|l|l|l}
\hline Zones & Total screened patients & $\begin{array}{l}\text { Percentage of screened } \\
\text { patients from each zone }\end{array}$ & Zone wise prevalence \\
\hline North & 276 & 5.3 & 34.06 \\
\hline East & 943 & 18.3 & 22.59 \\
\hline West & 1646 & 31.9 & 21.75 \\
\hline Central & 554 & 10.7 & 12.27 \\
\hline Northeast & 106 & 2.1 & 14.15 \\
\hline South & 1638 & 31.7 & 22.65 \\
\hline
\end{tabular}

At 194 centers, Diabetics found voluntarily assessed by citizens of society using a formal procedure that was given for evaluation by society. The findings were analyzed to assess the occurance of DR in the sample population and to classify age-related and historical risk factors such as length of diabetes, use of insulin, and other end-organ diseases using the Chi-square method. A total of 6218 diabetics known to have been screened. In total, 5130 forms of data entry were deemed suitable for further review. Approximately 61.2 percent were males, 88.6 percent were between the ages of 40 and 80 , nearly two-thirds of patients were from the western and southern zones, and more than half had diabetes over 5 years.

Table III. P Occurance of diabetic retinopathy about diabetes period mellitus.

\begin{tabular}{|c|c|}
\hline Duration of diabetes mellitus & Prevalence of diabetic retinopathy \\
\hline Less than 6 months & 9.23 \\
\hline 6 months to 5 years & 15.12 \\
\hline More than 5 years & 35.12 \\
\hline
\end{tabular}

Table -IV Occurance of diabetic retinopathy in patients with other end--organ disease.

\begin{tabular}{|c|c|}
\hline $\begin{array}{c}\text { Relation to other end organ } \\
\text { disease }\end{array}$ & Prevalence (\%) \\
\hline Renal & 42.86 \\
\hline Cardiac & 29.34 \\
\hline Stroke & 31.82 \\
\hline Others & 22.47 \\
\hline Not Complications & 21.06 \\
\hline Multiple & 48.72 \\
\hline
\end{tabular}

The effect of diabetic retinopathy on people who have other organ diseases is quite common.
Chart -I. Zone-wise occurance of diabetic retinopathy; This represents the commonness of DR in patients in India.

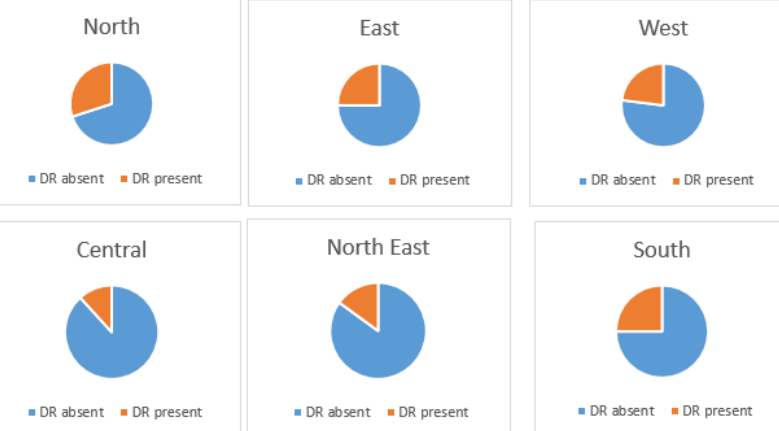

Table -V. Distribution of DR

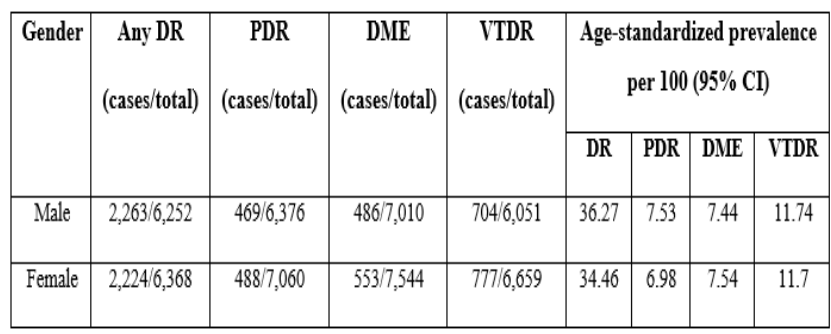

age-standardised prevalence

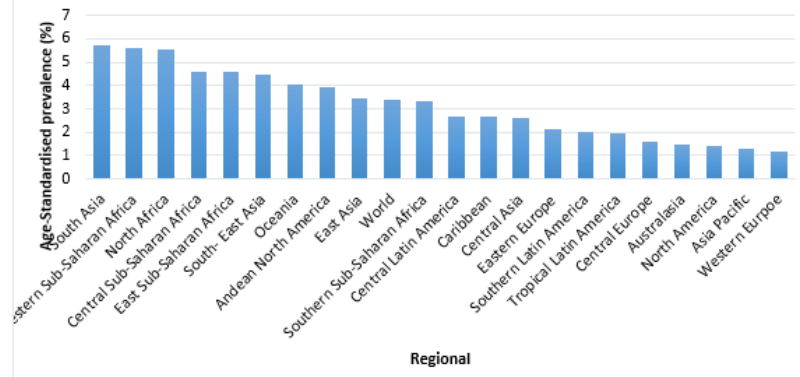

Fig 2.The age-standardised prevalence (all ages) of Visual Impairment (Blindness + MSVI)

\section{LITERATURE REVIEW}

Franklin et al.(2014), This research work provides a technique for segmentation of retinal vessels that can be used in retinal image analysis of machines. This experimental technique can be a pre-screening tool to detect diabetic retinopathy early on. The methods used in analysis can be used anonymously in retinal images to classify and interpret vascular structures.

Fleming et al,2007 , Computerized image processing is extensively followed to shorten the task of grading images resultant from the diabetic retinopathy screening programs. Attempting to correct exudates in retinal images is a primary goal for automatic identification being one of the indicators that the disease has advanced to a point that needs to be listened to as an ophthalmologist.

Diabetic images and normal images are taken from a fundus camera, processed and analyzed for back-propagation on a computer using a neural network. The network had been Instructed in acknowledging functionalities of the retinal image. It evaluated the impacts of numerous network variables and automatic filtering strategies.

Published By:

Blue Eyes Intelligence Engineering

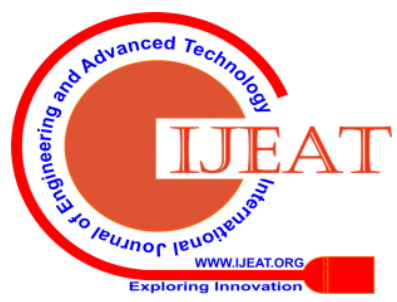


Diabetic and normal images were then randomized to assess network performance. The model shows $88.4 \%$ sensitivity and $83.5 \%$ specificity .Gardner et al.1996)

This paper attempted to detect exudates using neural network back propagation (Karegowda et al.,2011). The publicly available DIARETDB1 dataset for diabetic retinopathy was used in the assessment process. The optic disk is neglected to avoid the optic disk from interfering with detection of exudates. The model shows Sensitivity of $93.97 \%$, Specificity of $90 \%$ and Accuracy of $94.65 \%$.

Dupas et al.(2010) Automated microaneurysm and exudate identification was functionalise to two small image databases storage that manually marked those lesions on. A computer-based diagnostic system was then developed and tested for DR and ME risk recognition and rating, use of such a huge database comprising both ordinary and compulsive images and auto gradation comparison.

Preprocessing of Comparison improvement is extended until four features are collected as input frequency variables, normal frequency differentiation, hue and several angle pixel resolution, to provide coarse segmentation as data variables utilizing FCM clustering tool (Sopharak et al.,2009).. The model showed a Sensitivity of $90.28 \%$, specificity of $93.24 \%$ and Accuracy of $89.11 \%$.

This suggests an automated procedure for the identification of rough exudates, a lesion associated with diabetic retinopathy. Using a statistical description, the algorithm based on their color and their edges, adding an edge identifying to address them. In this way, we test the method's robustness to make it suitable to a clinical setting. The model showed a sensitivity of 79.62\% (Sanchez et al., 2004)

Rao et al.(2015) Among the difficult and important elements of managing primary open angle glaucoma (OAG) is identifying glaucoma progression. It is caused by pressure accumulation inside the eye. Detecting glaucomatous progression is important and demanding of handling firstly open angle glaucoma (OAG). The model showed an accuracy of $90.6 \%$.

An effective method for identifying exudates as hard and soft exudates in this article(Rajput et al., 2014). To remove noise, the retinal photograph in the color space of CIELAB is processed. Then after, the network of capillary is separated to allow the identification and removal of optic disks. Using Hough transform method, the optic disks are removed. The victim exudates are identified by using kmeans clustering algorthim. The model showed a sensitivity of $95.92 \%$ and accuracy of $99.70 \%$.

Classification schemes are developed and tested to deduct the presence or absence of DR. The detection rule is depends up on the problem of binary-hypothesis testing which clarifies yes / no decisions with the question. It also shows an overview of the Bayes output optimality criterion applied to DR. On the real-world data, the proposed DSS is evaluated. The model showed specificity of 67\%(Kahai et al., 2006)

Prasad et al. (2015) This analysis suggests that usage of morphological techniques and methods of segmentation to identify the capillary, microaneurysms and hard \& soft exudates. The representation of the retinal fundus is split into sub frames. Diverse attributes were derived through the image of the retinal fundus. On the extracted features hair wavelet transformations are applied. The main technique for the analysis of components is then applied for better selection of features. For the detection and classification of the images as diabetic or non-diabetic, neural network back propagation techniques were employed. The model showed an accuracy of $93.8 \%$.

This paper explores and suggests a optimally modified morphological operators technique to be used on the lowcontrast images of patients with diabetic retinopathy for exudate detection (Sopharak et al.,2008). These automatically observed exudates are confirmed as compared with the hand-drawn ground-truths of professional ophthalmologists. The model showed a sensitivity and specificity is $80 \%$ and $99.5 \%$.

Kwasigroch et al.(2018) To improve system performance, We suggested a separate class coding methodology that enabled details to be included on the value of the discrepancy here between expected performance and the targeted performance in the subjective function monitored during neural network training. We used normal precision measurements and a quadratic weighted Kappa score to check classification capacity of the employed models. The model showed an accuracy of about $82 \%$.

We introduced a brief structure to the convolutionary neural network architecture by emerging a pre-processing layered and convolution layer for maximise the output for the convolutionary neural network classifier (Khojaste et al.,2018). Two image enhancement techniques such as Contrast enhancement technique and Adaptive histogram equalization with a minimal contrast technique. The model showed an accuracy of $87.6 \%$.

Priya et al.(2012)This paper proposed two models such as Probabilistic Neural Network and Support Vector Machine to diagnose diabetic retinopathy, and compares their efficiency. When diabetes progresses, a patient's vision can initialized to deteriorate and lead to diabetes retinopathy. Two classes are established, namely nonproliferative diabetes retinopathy and proliferative diabetes retinopathy. PNN has an accuracy of $92.5 \%$ and SVM has an accuracy of $93 \%$.

The project's aim is to identify retinal micro-aneurysms and exudates using classifier for automated DR screening(Gupta et al., 2015). It is necessary to implement an automated DR screening system for detecting dark lesions and bright lesions in photographs of digital funds. To detect retinal micro-aneurysms and exude images from retinal funds. The model showed a sensitivity and specificity of $87 \%$ and $100 \%$, accuracy of $86 \%$.

Geetharamani et al.(2017) Diabetic Retinopathy, a primary leads of blindness, is discussed in this study. For define Diabetic Retinopathy, a two-tier system is adopted. The suggested technique is evaluated by the UCI Machine Learning Repository on Diabetic Retinopathy Drebechen Dataset. The evolved rules are evaluated and the best rules are created through 3 fold cross validation.

Diabetic Retinopathy is an eye disease caused by diabetes over the huge term (Athira et al.,2019). In our paper we suggest an approach for the diagnosis of DR from R-CNN (Regional Convolution Neural Network) digital fundus images. R-CNN is highly accurate and resistant to lesion detection. Throughout our work, we have implemented a new strategy, where the whole picture was segmented and only the regions of interest were taken for further analysis.

Published By:

Blue Eyes Intelligence Engineering DOI: 10.35940/ijeat.C6397.049420

Journal Website: www.ijeat.org

\& Sciences Publication

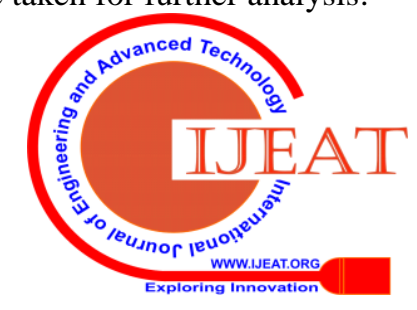


In our process we used 10 layers of R-CNN, trained it on 129 fundus images and checked 111 images on them.Both images were divided into two categories, i.e., with DR and without DR. This R-CNN (Regional CNN) approach was found to be fast and accurate with an accuracy of approximately $94 \%$.

Sopharak et al. (2008) A identifying of lesions in digital fundus images is required for development of an automated diabetic retinopathy screening system. Microaneurysms are the first symptom of diabetic retinopathy in clinical treatment. Microaneurysm numbers are used to denote the situation of the condition. Early detection of microaneurysm may use to lower the risk of blindness. This study discusses a set of efficiently adapted morphological regulators which are used for microaneurysm detection on non-dilated pupils and significantly higher-contrast retinal images. The microaneurysms observed are checked when compared with the ophthalmologists ' hand-drawn ground-truth. As a outcome, 81.61, 99.99, 63.76 and 99.98 percent respectively were the sensitivity, specificity, precision and accuracy.

Diabetic Retinopathy and blindness problems diabetic patients facing. As the number of patients with diabetes is steadily increasing, this also results in an increase in the data. Therefore, the use of data mining methods is important to obtain the useful information and unseen knowledge. DM plays a major role in DR as it can be utilise to society's better health. For retinal fundus images there are many techniques and algorithms which help to diagnose. This paper discusses, classifies and compares the previously proposed algorithms and methods with a view to creating better and more effective algorithms. This paper presents a summary view of different data mining techniques which shows that KNN and SVM have given the best accuracies. This review paper can act as a resource for future researchers to use data mining techniques to predict diabetic retinopathy.(Rathi, 2017)

Ananthapadmanaban et al.(2014) The most frequent of eye disease is diabetic retinopathy, is affected by complications which occur when capillary in the retina weaken. When early detection is not achieved it results in vision loss. Depending on the modeling objective many data mining techniques serve different purposes. The results of the various techniques for classifying data mining were tested using a different method. To predict early detection of diabetic retinopathy eye disease, we used Naive bayes and Support Vector Machine, and the results indicate that the Naive bayes test was 89.47 percent accurate.

Brief insight into the identification of DR in human eyes using various forms of preprocessing \& segmentation techniques is provided in this research article (Kumaran et al.). The detection actually depends on the RNFL network region. If the total area of the nerve fiber is lower, it will be affected by diabetic retinopathy (DR) and if the region of the nerve network is larger, therefore diabetic retinopathy will not impact the eyes and is therefore normal. It is a wellknown fact that diabetics play a critical role in the wellbeing of humans and affect all organs. One such organ that is in man's possession. The DR will lead to a loss of vision in the human eye as the optic nerve is connected to the brain. The retinal fundus images are widely used in disease-affected images to diagnose \& interpret disease. Raw images of the retinal fundus are difficult to process with machine learning algos. It is in this very context that a survey is being given here.
Kauppi et al.(2006) The advancement of image processing techniques to a high level where the finding can be transferred from research laboratories to practice includes the following: protocols approved and applied to test the techniques, protocols similar to the strict medical care regulations, and medicine research. They suggested the first step towards a systematic review of methods for detecting diabetic retinopathy findings. DIARETDB0 is at al complicated database in many respects but in reality it corresponds to the situation: the images are uncalibrated, the expert assessment is free form and the displays used to interpret the images are uncalibrated.

Diabetic retinopathy is among Europe's most common causes of blindness. Effective therapies do exist however. In more than 50 per cent of all cases, correct and early diagnosis and proper treatment procedure will prevent blindness. As a screening tool for diabetic retinopathy, digital imaging is becoming available. In addition to providing a high-quality permanent retinal appearance record that can be used to track development or reaction to treatment and that can be checked by an ophthalmologist, digital images have the ability to be processed by predictive analytics systems. Identified the primary creation of a method for providing automated of digital photograph taken as part of our clinic's daily monitoring of diabetic retinopathy.

A deep-learning enhanced DR detection algorithm reaches significantly better performance than a earlierly reported, but virtually similar, technique not using deep learning (Abramoff et al.,2016). Deep learning algorithms have the suitability to develop DR screening performance and prevent this devastating disease from vision impairment and blindness.

Table VI: Related Work

\begin{tabular}{|c|c|c|c|c|}
\hline $\begin{array}{l}\mathrm{S} / \\
\mathbf{N} \\
\mathbf{O} .\end{array}$ & Author Year & $\begin{array}{l}\text { Feature } \\
\text { Selection } \\
\text { Techniques } \\
\text { Used }\end{array}$ & $\begin{array}{l}\text { Machine } \\
\text { Learning } \\
\text { techniques } \\
\text { used }\end{array}$ & $\begin{array}{l}\text { Performan } \\
\text { ce } \\
\text { Evaluation }\end{array}$ \\
\hline 1 & $\begin{array}{l}\text { S. Wilfred } \\
\text { Franklin , S. } \\
\text { Edward Rajan } \\
\text { ( 2014) }\end{array}$ & $\begin{array}{l}\text { Segmentation } \\
\text { technique }\end{array}$ & $\begin{array}{l}\text { Back } \\
\text { Propagation } \\
\text { algorithm }\end{array}$ & $\begin{array}{l}\text { Accuracy: } \\
95.03 \%\end{array}$ \\
\hline 2 & $\begin{array}{l}\text { Wong Li } \\
\text { Yun(2007) }\end{array}$ & $\begin{array}{l}\text { Image } \\
\text { processing } \\
\text { techniques }\end{array}$ & $\begin{array}{l}\text { Three-layer } \\
\text { feedforwar } \\
\text { d neural } \\
\text { network }\end{array}$ & $\begin{array}{l}90 \% \\
\text { sensitivity, } \\
100 \% \\
\text { specificity }\end{array}$ \\
\hline 3 & $\begin{array}{l}\text { Alan D } \\
\text { Fleming(2007 } \\
\text { ) }\end{array}$ & $\begin{array}{l}\text { Multi-scale } \\
\text { morphological } \\
\text { process. }\end{array}$ & $\begin{array}{l}\text { Retinopath } \\
\text { y screening } \\
\text { programme } \\
\text { s }\end{array}$ & $\begin{array}{l}95 \% \\
\text { sensitivity } \\
84.6 \% \\
\text { specificity }\end{array}$ \\
\hline 4 & G Gardner & $\begin{array}{l}\text { Digital filtering } \\
\text { techniques }\end{array}$ & $\begin{array}{l}\text { Back } \\
\text { propagation } \\
\text { neural } \\
\text { network. }\end{array}$ & $\begin{array}{l}88.4 \% \\
\text { sensitivity, } \\
83.5 \% \\
\text { specificity }\end{array}$ \\
\hline 5 & $\begin{array}{l}\text { Asha Gowda } \\
\text { Karegowda(2 } \\
011)\end{array}$ & $\begin{array}{l}\text { Decision tree } \\
\text { and GA-CFS }\end{array}$ & $\begin{array}{l}\text { Back } \\
\text { propagation } \\
\text { neural } \\
\text { network }\end{array}$ & $\begin{array}{l}96.97 \% \\
\text { Sensitivity, } \\
\text { 100\%Speci } \\
\text { ficity, } \\
98.45 \% \\
\text { accuracy. }\end{array}$ \\
\hline 6 & $\begin{array}{l}\text { B. } \\
\text { Dupas(2010) }\end{array}$ & $\begin{array}{l}\text { Embedded } \\
\text { method } \\
\text { (Regression) }\end{array}$ & $\begin{array}{l}\text { Grading of } \\
\text { DR and risk } \\
\text { of } \mathrm{ME}\end{array}$ & $\begin{array}{l}72.8 \% \\
\text { sensitivity, } \\
70.8 \% \\
\text { specificity. }\end{array}$ \\
\hline
\end{tabular}

Published By:

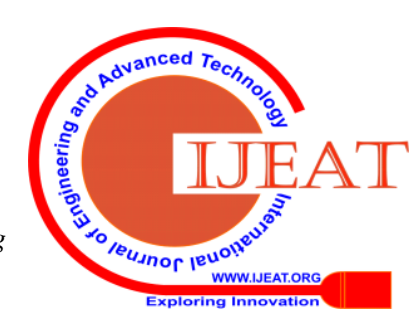


Knowledge based Expert System for Predicting Diabetic Retinopathy using Machine Learning Algorithms

\begin{tabular}{|c|c|c|c|c|}
\hline 7 & $\begin{array}{l}\text { T. } \\
\text { Teng(2005) }\end{array}$ & PSO & $\begin{array}{l}\text { Image } \\
\text { processing } \\
\text { algorithms } \\
\end{array}$ & $\begin{array}{l}100 \% \\
\text { sensitivity. }\end{array}$ \\
\hline 8 & $\begin{array}{l}\text { Gwenol’e } \\
\text { Quellec(2017 } \\
\text { ) }\end{array}$ & $\begin{array}{l}\text { Correlation } \\
\text { Matrix }\end{array}$ & $\begin{array}{l}\text { CADe } \\
\text { algorithms }\end{array}$ & Group form \\
\hline 9 & $\begin{array}{l}\text { Akara } \\
\text { Sopharak(200 } \\
\text { 9) }\end{array}$ & $\begin{array}{l}\text { Correlation } \\
\text { Matrix with } \\
\text { Heat maps }\end{array}$ & $\begin{array}{l}\text { Fuzzy } \\
\text { CMeans } \\
\text { (FCM) } \\
\text { clustering }\end{array}$ & $\begin{array}{l}\text { PPV } \\
42.77 \%, P L \\
\text { R 224.26\%, } \\
\text { accuracy } \\
99.11 \% \\
\end{array}$ \\
\hline 10 & $\begin{array}{lr}\text { C. I. } \\
\text { Sánchez(2005 } \\
\text { ) }\end{array}$ & $\begin{array}{l}\text { Univariate } \\
\text { Selection }\end{array}$ & $\begin{array}{l}\text { statistical } \\
\text { classificatio } \\
\mathrm{n}\end{array}$ & $\begin{array}{l}79.62 \% \\
\text { sensitivity }\end{array}$ \\
\hline 11 & $\begin{array}{l}\text { P.V.Rao(2014 } \\
\text { ) }\end{array}$ & $\begin{array}{l}\mathrm{Z} \quad \text { Score } \\
\text { Normalization }\end{array}$ & $\begin{array}{l}\text { Artificial } \\
\text { Neural } \\
\text { Network } \\
\text { (ANN) }\end{array}$ & $\begin{array}{l}90.6 \% \\
\text { accuracy }\end{array}$ \\
\hline 12 & $\begin{array}{l}\text { Dr. G. G. } \\
\text { Rajput(2014) }\end{array}$ & $\begin{array}{l}\text { Embedded } \\
\text { methods }\end{array}$ & $\begin{array}{l}\text { k-means } \\
\text { clustering } \\
\text { technique. }\end{array}$ & $\begin{array}{l}95.92 \% \\
\text { sensitivity, } \\
92.28 \% \\
\text { predictive } \\
\text { value, } \\
99.70 \% . \\
\text { accuracy. }\end{array}$ \\
\hline 13 & $\begin{array}{l}\text { P. } \\
\text { Kaha(2005) }\end{array}$ & $\begin{array}{l}\text { Wrapper } \\
\text { technique }\end{array}$ & $\begin{array}{l}\text { Decision } \\
\text { support } \\
\text { system } \\
\text { (DSS) }\end{array}$ & $\begin{array}{l}67 \% \\
\text { specificity }\end{array}$ \\
\hline 14 & $\begin{array}{l}\text { Deepthi } \quad \text { K } \\
\text { Prasad(2015) }\end{array}$ & $\begin{array}{l}\text { Wavelet } \\
\text { transformations }\end{array}$ & $\begin{array}{l}\text { Back } \\
\text { propagation } \\
\text { neural } \\
\text { network }\end{array}$ & $\begin{array}{l}93.8 \% \\
\text { accuracy }\end{array}$ \\
\hline 15 & $\begin{array}{l}\text { Akara } \\
\text { Sopharak(201 } \\
\text { 8) }\end{array}$ & $\begin{array}{l}\text { Wrapper } \\
\text { method }\end{array}$ & $\begin{array}{l}\text { Exudate } \\
\text { detection } \\
\text { and } \\
\text { classificatio } \\
\mathrm{n}\end{array}$ & $\begin{array}{l}80 \% \text { sensiti } \\
\text { vity } \\
99.5 \% \text { speci } \\
\text { ficity }\end{array}$ \\
\hline 16 & $\begin{array}{l}\text { Manoj } \\
\text { Raju(2017) }\end{array}$ & $\begin{array}{l}\text { Detecting the } \\
\text { laterality of } \\
\text { fundus image }\end{array}$ & $\begin{array}{l}\text { Deep } \\
\text { learning } \\
\text { application } \\
\text { in } \\
\text { classifying }\end{array}$ & $\begin{array}{l}80.28 \% \\
\text { sensitivity } \\
, 92.29 \% \\
\text { specificity , } \\
93.28 \% \\
\text { accuracy }\end{array}$ \\
\hline 17 & $\begin{array}{l}\text { Arkadiusz } \\
\text { Kwasigroch(2 } \\
018)\end{array}$ & $\begin{array}{l}\text { Embedded(Regr } \\
\text { ession) }\end{array}$ & $\begin{array}{l}\text { Deep } \\
\text { convolution } \\
\text { al neural } \\
\text { networks } \\
\text { (CNN) }\end{array}$ & $\begin{array}{l}82 \% \\
\text { accuracy }\end{array}$ \\
\hline 18 & $\begin{array}{l}\text { Xiaogang } \\
\text { L(2017) }\end{array}$ & Filter methods & $\begin{array}{l}\text { Convolutio } \\
\text { nal Neural } \\
\text { Networks } \\
\text { (CNNs) }\end{array}$ & Group form \\
\hline 19 & P. Khojasteh & $\begin{array}{l}\text { Embedded(LAS } \\
\text { SO Regression) }\end{array}$ & $\begin{array}{l}\text { Convolutio } \\
\text { nal neural } \\
\text { network } \\
\text { architecture }\end{array}$ & $\begin{array}{l}87.6 \% \\
\text { accuracy }\end{array}$ \\
\hline 20 & R.Priya(2012) & SVM & $\begin{array}{l}\text { Probabilisti } \\
\text { c Neural } \\
\text { network } \\
\text { (PNN) }\end{array}$ & $\begin{array}{l}89.60 \% \\
\text { accuracy }\end{array}$ \\
\hline 21 & $\begin{array}{l}\text { Kanika } \\
\text { Verma }\end{array}$ & $\begin{array}{l}\text { Random Forests } \\
\text { technique }\end{array}$ & $\begin{array}{l}\text { Density } \\
\text { analysis } \\
\text { and } \\
\text { bounding } \\
\text { box } \\
\text { techniques. }\end{array}$ & $\begin{array}{l}90 \% \\
\text { accuracy }\end{array}$ \\
\hline 22 & $\begin{array}{l}\text { Swati } \\
\text { Gupta(2015) }\end{array}$ & $\begin{array}{l}\text { Recursive } \\
\text { Elimination }\end{array}$ & $\begin{array}{l}\text { Computatio } \\
\text { nal } \\
\text { techniques }\end{array}$ & $\begin{array}{l}87 \% \\
\text { sensitivity, } \\
100 \% \text { specif } \\
\text { icity } \\
86 \% \text { accura } \\
\text { cy }\end{array}$ \\
\hline
\end{tabular}

\begin{tabular}{|c|c|c|c|c|}
\hline 23 & $\begin{array}{l}\text { R. } \\
\text { GeethaRaman } \\
\text { i(2017) }\end{array}$ & $\begin{array}{l}\text { Wrapper and } \\
\text { filter methods }\end{array}$ & $\begin{array}{l}\text { UCI } \\
\text { Machine } \\
\text { Learning } \\
\text { Repository }\end{array}$ & $\begin{array}{l}96.14 \% \\
\text { accuracy }\end{array}$ \\
\hline 24 & athira2019 & Filter methods & $\begin{array}{l}\text { R-CNN } \\
\text { (Regional } \\
\text { CNN) }\end{array}$ & $93.8 \%$ \\
\hline 25 & priya2013 & Binary patterns & SVM & $95.38 \%$ \\
\hline 26 & chetoui2018 & $\begin{array}{ll}\text { Local } & \text { Ternary } \\
\text { Pattern } & \end{array}$ & $\begin{array}{l}\text { SVM with } \\
\text { a Radial } \\
\text { Basis } \\
\text { Function } \\
\text { kernel } \\
\text { (SVMRBF) }\end{array}$ & $93.10 \%$ \\
\hline 27 & wan2018 & $\begin{array}{ll}\text { Filter } & \text { and } \\
\text { wrapper } & \\
\text { techniques } & \end{array}$ & $\begin{array}{l}\text { Convolutio } \\
\text { nary neural } \\
\text { networks }\end{array}$ & $95.68 \%$ \\
\hline 28 & sopharak2012 & LTP & $\begin{array}{l}\text { Bayes } \\
\text { classifier }\end{array}$ & $\begin{array}{l}85.68- \\
\text { sensitivity, } \\
99.99- \\
\text { specificity, } \\
83.34 \\
\text { precision } \\
99.99- \\
\text { accuracy }\end{array}$ \\
\hline 29 & rathi2017 & $\begin{array}{l}\text { Data mining } \\
\text { techniques }\end{array}$ & $\begin{array}{l}\text { Artificial } \\
\text { neural } \\
\text { network }\end{array}$ & $94.8 \%$ \\
\hline 30 & sopharak2008 & $\begin{array}{l}\text { Wrapper } \\
\text { methods }\end{array}$ & $\begin{array}{l}\text { SVM } \\
\text { Classifier }\end{array}$ & $99.98 \%$ \\
\hline 31 & rathi2017 & Filter methods & $\begin{array}{l}\text { SVM } \\
\text { Classifier }\end{array}$ & $90 \%$ \\
\hline 32 & $\begin{array}{l}\text { kandhasamy2 } \\
019\end{array}$ & $\begin{array}{l}\text { Local Binary } \\
\text { Patterns, Colour } \\
\text { Moments }\end{array}$ & $\begin{array}{l}\text { SVM } \\
\text { classifier }\end{array}$ & 98.01 \\
\hline 33 & $\begin{array}{l}\text { ananthapadm } \\
\text { anaban2014 }\end{array}$ & $\begin{array}{l}\text { Images by } \\
\text { descriptors and } \\
\text { Hu moment of } \\
\text { GIST }\end{array}$ & $\begin{array}{l}\text { Naive baye } \\
\text { s and Supp } \\
\text { ort Vector } \\
\text { Machine } \\
\text { Rapid } \\
\text { Miner Tool }\end{array}$ & 83.37 \\
\hline 34 & kumaran & $\begin{array}{l}\text { RNFL network } \\
\text { region }\end{array}$ & $\begin{array}{l}\text { Artificial } \\
\text { neural } \\
\text { network }\end{array}$ & $85 \%$ \\
\hline 35 & akram2014 & NPDR lesions & $\begin{array}{l}\text { Gaussian } \\
\text { Mixture } \\
\text { Model }\end{array}$ & $98.52 \%$ \\
\hline 36 & kauppi2006 & PSO & $\begin{array}{l}\text { Image } \\
\text { database, } \\
\text { ground } \\
\text { truth and } \\
\text { evaluation } \\
\text { methodolog } \\
\text { y }\end{array}$ & $\begin{array}{l}\text { Sensitivity } \\
79 \%\end{array}$ \\
\hline 37 & ege2000 & $\begin{array}{l}\text { Mahalanobis } \\
\text { classifier }\end{array}$ & $\begin{array}{l}\text { Bayes } \\
\text { classifier, } \\
\text { KNN } \\
\text { classifier }\end{array}$ & $93 \%$ \\
\hline 38 & abramoff2016 & lesion detectors & CNN & $\begin{array}{l}\text { Sensitivity- } \\
96.8 \% \\
\text { specificity } \\
87.0 \%\end{array}$ \\
\hline
\end{tabular}

\section{METHODOLOGY}

Particle swarm optimization has been applied to numerous areas in optimization and in combination with other existing algorithms. This method performs the search of the optimal solution through agents, referred to as particles, whose trajectories are adjusted by a stochastic and a deterministic component.

Published By:

Blue Eyes Intelligence Engineering

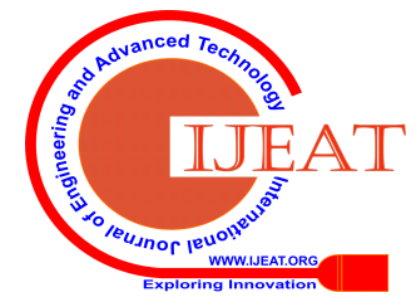


The selected features are then classified using the following algorithms: Decision Tree, Random Forest, Support Vector Machine.

Figure 3 depicts the System Architecture Diagram

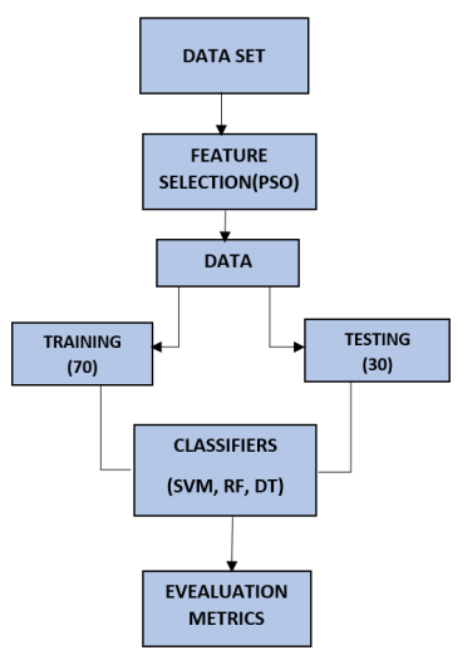

Fig. 3 System Architecture

\section{RESULT ANALYSIS}

The performance of the proposed work is analyzed using the following metrics: accuracy, sensitivity and specificity.

Table VII- Comparison results of classifiers with regard to Accuracy

\begin{tabular}{|l|c|c|c|}
\hline \multicolumn{4}{|c|}{ Sensitivity in \% } \\
\hline Classifiers & $\begin{array}{c}\text { No. of } \\
\text { features } \\
(20)\end{array}$ & $\begin{array}{c}\text { No. of } \\
\text { features } \\
(25)\end{array}$ & $\begin{array}{c}\text { No. of } \\
\text { features } \\
(30)\end{array}$ \\
\hline SVM & 84.6 & 87 & 96.6 \\
\hline $\begin{array}{l}\text { Random } \\
\text { Forest }\end{array}$ & 90.1 & 94.3 & 94 \\
\hline $\begin{array}{l}\text { Decision } \\
\text { Tree }\end{array}$ & 90 & 94 & 95.4 \\
\hline
\end{tabular}

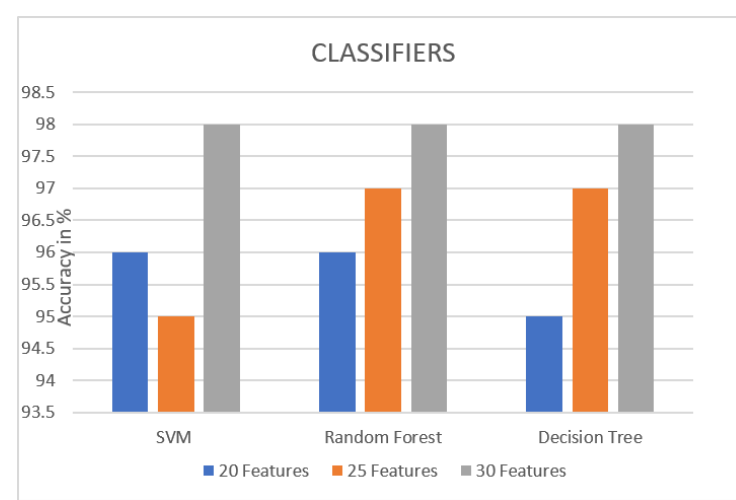

Fig. 4 Comparison results of classifiers with regard to Accuracy

Table VIII- Comparison results of classifiers with regard to Specificity

\begin{tabular}{|l|c|c|c|}
\hline \multicolumn{4}{|c|}{ Specificity in \% } \\
\hline Classifiers & $\begin{array}{c}\text { No. of } \\
\text { features }\end{array}$ & $\begin{array}{c}\text { No. of } \\
\text { features }\end{array}$ & $\begin{array}{c}\text { No. of } \\
\text { features }\end{array}$ \\
\hline
\end{tabular}

\begin{tabular}{|l|c|c|c|}
\hline & $(20)$ & $(25)$ & $(30)$ \\
\hline SVM & 82.5 & 95.5 & 96.5 \\
\hline $\begin{array}{l}\text { Random } \\
\text { Forest }\end{array}$ & 85 & 91 & 95 \\
\hline $\begin{array}{l}\text { Decision } \\
\text { Tree }\end{array}$ & 83.5 & 84 & 94.5 \\
\hline
\end{tabular}

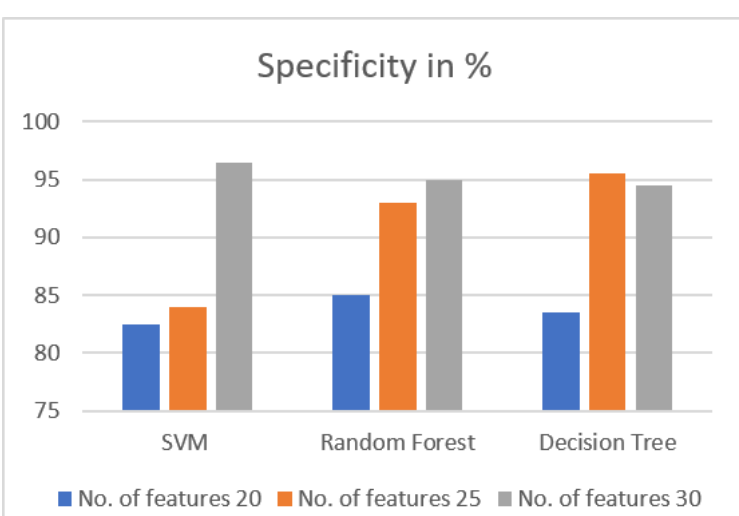

Fig. 5 Comparison results of classifiers with regard to Specificity

Table 9 represents the comprasion between the classifiers terms of accuracy which is figured in fig. 6

Table IX-Comparison results of classifiers with regard to Sensitivity

\begin{tabular}{|l|c|c|c|}
\hline \multicolumn{4}{|c|}{ ACCURACY in \% } \\
\hline CLASSIFIERS & $\begin{array}{c}\text { No. of } \\
\text { features } \\
20\end{array}$ & $\begin{array}{c}\text { No. of } \\
\text { features } \\
25\end{array}$ & $\begin{array}{c}\text { No. of } \\
\text { features } \\
30\end{array}$ \\
\hline SVM & 96 & 95 & 98 \\
\hline Random Forest & 96 & 97 & 98 \\
\hline Decision Tree & 95 & 97 & 98 \\
\hline
\end{tabular}

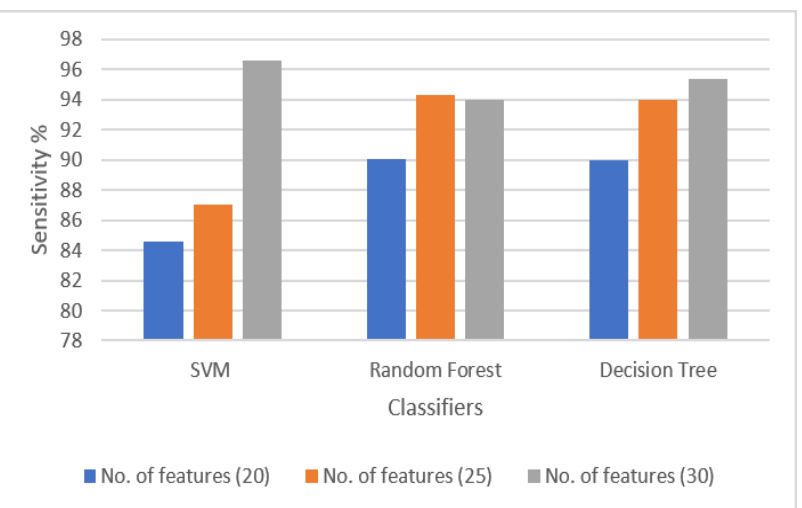

Fig. 6 Comparison results of classifiers with regard to Sensitivity

Published By:

Blue Eyes Intelligence Engineering

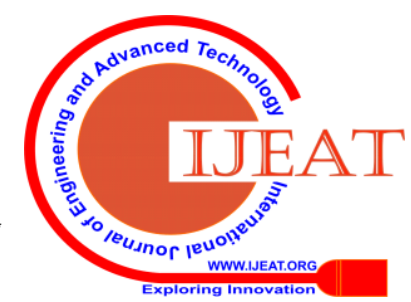




\section{CONCLUSION}

Thus the paper examines the Diabetic retinopathy using PSO Feature Selection algorithm on three different Classifiers SVM Classifier accuracy (98), sensitivity (96.6) and specificity (96.5). SVM Classifier have got the maximum metrics percentage for PSO Feature selection algorithm.

\section{REFERENCES}

1. Franklin, S. Wilfred, and S. Edward Rajan. "Computerized screening of diabetic retinopathy employing blood vessel segmentation in retinal images." biocybernetics and biomedical engineering 34.2 (2014): 117-124.

2. Yun, Wong $\mathrm{Li}$, et al. "Identification of different stages of diabetic retinopathy using retinal optical images." Information sciences 178.1 (2008): 106-121.

3. Fleming, Alan D., et al. "Automated detection of exudates for diabetic retinopathy screening." Physics in Medicine \& Biology 52.24 (2007): 7385.

4. Gardner, G. G., et al. "Automatic detection of diabetic retinopathy using an artificial neural network: a screening tool." British journal of Ophthalmology 80.11 (1996): 940-944.

5. Gowda Karegowda, Asha, et al. "Exudates Detection in Retinal Images using Back Propagation Neural Network." International Journal of Computer Applications 25.3 (2011): 25-31.

6. Dupas, Bénédicte, et al. "Evaluation of automated fundus photograph analysis algorithms for detecting microaneurysms, haemorrhages and exudates, and of a computer-assisted diagnostic system for grading diabetic retinopathy." Diabetes \& metabolism 36.3 (2010): 213-220.

7. Teng, Thomas, Martin Lefley, and D. Claremont. "Progress towards automated diabetic ocular screening: a review of image analysis and intelligent systems for diabetic retinopathy." Medical and Biological Engineering and Computing 40.1 (2002): 2-13.

8. Quellec, Gwenolé, et al. "Deep image mining for diabetic retinopathy screening." Medical image analysis 39 (2017): 178-193.

9. Sopharak, Akara, Bunyarit Uyyanonvara, and Sarah Barman. "Automatic exudate detection from non-dilated diabetic retinopathy retinal images using fuzzy c-means clustering." sensors 9.3 (2009): 2148-2161.

10. Sánchez, Clara I., et al. "Retinal image analysis to detect and quantify lesions associated with diabetic retinopathy." The 26th Annual International Conference of the IEEE Engineering in Medicine and Biology Society. Vol. 1. IEEE, 2004.

11. Rao, P. V., R. Gayathri, and R. Sunitha. "A novel approach for design and analysis of diabetic retinopathy glaucoma detection using cup to disk ration and ANN." Procedia Materials Science 10 (2015): 446454.

12. Rajput, G. G., and Preethi N. Patil. "Detection and classification of exudates using k-means clustering in color retinal images." 2014 Fifth International Conference on Signal and Image Processing. IEEE, 2014.

13. Kahai, Pallavi, Kameswara Rao Namuduri, and H. Thompson. "A decision support framework for automated screening of diabetic retinopathy." International journal of biomedical imaging 2006 (2006).

14. Prasad, Deepthi K., L. Vibha, and K. R. Venugopal. "Early detection of diabetic retinopathy from digital retinal fundus images." 2015 IEEE Recent Advances in Intelligent Computational Systems (RAICS). IEEE, 2015.

15. Sopharak, Akara, et al. "Automatic detection of diabetic retinopathy exudates from non-dilated retinal images using mathematical morphology methods." Computerized medical imaging and graphics 32.8 (2008): 720-727.

16. Raju, Manoj, et al. "Development of a Deep Learning Algorithm for Automatic Diagnosis of Diabetic Retinopathy." MedInfo. 2017.

17. Kwasigroch, Arkadiusz, Bartlomiej Jarzembinski, and Michal Grochowski. "Deep CNN based decision support system for detection and assessing the stage of diabetic retinopathy." 2018 International Interdisciplinary PhD Workshop (IIPhDW). IEEE, 2018.

18. Li, Xiaogang, et al. "Convolutional neural networks based transfer learning for diabetic retinopathy fundus image classification." 2017 10th International Congress on Image and Signal Processing, BioMedical Engineering and Informatics (CISP-BMEI). IEEE, 2017.

19. Khojasteh, Parham, et al. "Introducing a novel layer in convolutional neural network for automatic identification of diabetic retinopathy." in Medicine and Biology Society (EMBC). IEEE, 2018

20. Saha, Rituparna, Amrita Roy Chowdhury, and Sreeparna Banerjee. "Diabetic retinopathy related lesions detection and classification using machine learning technology." International Conference on Artificial Intelligence and Soft Computing. Springer, Cham, 2016.

21. R.Priya, P. Aruna. (2012). SVM and Neural Network based Diagnosis Applications. Volume 41- No.1, March 2012

22. Verma, Kanika, Prakash Deep, and A. G. Ramakrishnan. "Detection and classification of diabetic retinopathy using retinal images." 2011 Annual IEEE India Conference. IEEE, 2011.

23. Gupta, Swati, and A. M. Karandikar. "Diagnosis of diabetic retinopathy using machine learning." Journal of Research and Development 3.2 (2015): 1-6.

24. Athira, T. R., et al. "Automatic detection of Diabetic Retinopathy using R-CNN." (2019).

25. Priya, R., and P. Aruna. "Diagnosis of diabetic retinopathy using machine learning techniques." ICTACT Journal on soft computing 3.4 (2013): 563-575.

26. Chetoui, Mohamed, Moulav A. Akhloufi, and Mustanha Kardouchi. "Diabetic Retinopathy Detection Using Machine Learning and Texture Features." 2018 IEEE Canadian Conference on Electrical \& Computer Engineering (CCECE). IEEE, 2018.

27. Wan, Shaohua, Yan Liang, and Yin Zhang. "Deep convolutional neural networks for diabetic retinopathy detection by image classification." Computers \& Electrical Engineering 72 (2018): 274 282.

28. Sopharak, Akara, Bunyarit Uyyanonvara, and Sarah Barman. "Fine microaneurysm detection from non-dilated diabetic retinopathy retinal images using a hybrid approach." Proc. of the World Congress on Engineering. Vol. 2. 2012.

29. Rathi, P., and Anurag Sharma. "A review paper on prediction of diabetic retinopathy using data mining techniques." Int. J. Innov. Res. Technol 4.1 (2017): 292-297.

30. Sopharak, Akara, et al. "Automatic detection of diabetic retinopathy exudates from non-dilated retinal images using mathematica morphology methods." Computerized medical imaging and graphics 32.8 (2008): 720-727.

31. Rathi, P., and Anurag Sharma. "A review paper on prediction of diabetic retinopathy using data mining techniques." Int. J. Innov. Res. Technol 4.1 (2017): 292-297.

Kandhasamy, J. Pradeep, et al. "Diagnosis of diabetic retinopathy using multi level set segmentation algorithm with feature extraction Applications (2019): 1-16. [33] Ananthapadmanaban, K. R., and G. Parthiban. "Prediction of chances-diabetic retinopathy using data Technology 7.10 (2014): 1498-1503. the Detection of Diabetic Retinopathy in Human Eyes Using PreProcessing \& Segmentation Techniques." 7(4)

34. Akram, M. Usman, et al. "Detection and classification of retinal lesions for grading of diabetic retinopathy." Computers in biology and medicine 45 (2014): 161-171. [36] Kauppi, Tomi, et al "DIARETDB0: Evaluation database and methodology for diabetic retinopathy algorithms." Machine Vision and Pattern Recognition Research Group, Lappeenranta University of Technology, Finland 73 (2006): 1-17.

35. Ege, Bernhard M., et al. "Screening for diabetic retinopathy using computer based image analysis and statistical classification." Computer methods and programs in biomedicine 62.3 (2000): 165-175.

36. Abràmoff, Michael David, et al. "Improved automated detection of diabetic retinopathy on a publicly available dataset through integration of deep learning." Investigative ophthalmology \& visual science 57.13 (2016): 5200-5206. 


\section{AUTHORS PROFILE}

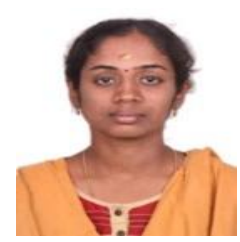

J. Jayashree received UG degree from Anna University, Tamilnadu and received PG degree from VIT University, Tamilnadu and $\mathrm{PhD}$ from VIT University. She is working as Assistant Professor Senior at VIT University, Vellore, Tamilnadu, India. Her research interests include Data Mining, Machine Learning. She had published a good number of papers in reputed Scopus Indexed Journals.

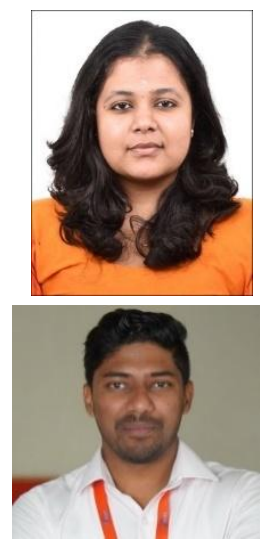

Sruthi R, I finished my schooling in Sishya School, Hosur. I am pursuing my B.Tech Computer Science with Information Security in VIT University Vellore

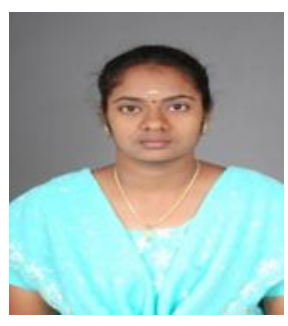

Ponnamanda Venkata Sairam, I finished my schooling in St.Ann's high school. I am pursuing my B.Tech Computer Science with Information Security in VIT University Vellore

J.Vijayashree received PG degree and $\mathrm{PhD}$ from VIT University,Tamilnadu. She is working as Assistant Professor Senior at VIT University, Vellore, Tamilnadu, India. Her research interests include Data Mining, Machine Learning. She had published a good number of papers in reputed Scopus Indexed Journals.

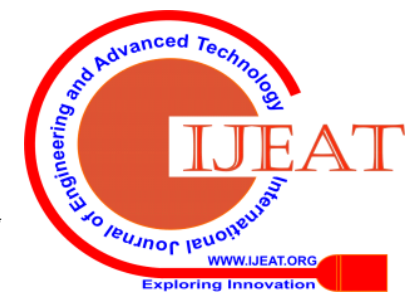

